\title{
Research Regarding the Effect of Vitamin E on Some Hematological Parameters in Toxic Stress Conditions in Rats
}

\author{
Ana Maria ZAGRAI (MAIEREAN) ${ }^{1}$, Aurel DAMIAN ${ }^{1}$, Marian GHITA², Gavrilă ZAGRAI ${ }^{2}$, Iulian \\ DUMITRESCU ${ }^{2}$, Cerasela VASILESCU ${ }^{2}$, Livia PAUN² ${ }^{2}$ Gabriel COTOR ${ }^{2 *}$ \\ ${ }^{1}$ Faculty of Veterinary Medicine, University of Agricultural Sciences and Veterinary Medicine Cluj-Napoca \\ ${ }^{2}$ Faculty of Veterinary Medicine, University of Agricultural Sciences and Veterinary Medicine Bucharest \\ *corresponding author: cotorg@yahoo.com
}

Bulletin UASVM Veterinary Medicine 77(1)/2020

Print ISSN 1843-5270; Electronic ISSN 1843-5378

doi:10.15835/buasvmcn-vm: 2019.0018

\begin{abstract}
Cadmium's mechanism of toxicity is manifested by its fixation in mitochondria, inhibition of cellular respiration and oxidative phosphorylation. Vitamin E could act as a protective factor against the harmful effect of Cadmium intoxication. The experimental animals were randomly allocated into 3 experimental groups of 6 rats. The collected blood samples were used to determine hematocrit, hemoglobin concentration, blood erythrocyte count and leukocyte count. The following derived red blood cell parameters were calculated in parallel according to the standard methodology. Between groups 1 and 2 there are no significant differences, a sign that vitamin E exerts an effective protective role. We found a significant increase in the white blood cell count and the neutrophil count in group 3 compared to group 1. Between groups 1 and 2 there are no significant differences, a sign that vitamin $\mathrm{E}$ has annihilated the cadmium-induced specific effect. In the case of cadmium poisoned rats, we found a decrease in the number of red blood cells, the hematocrit and the hemoglobin level, but also a significant increase in the number of white blood cells. If rats were treated with cadmium and vitamin $\mathrm{E}$, there were not significant differences from the control group.
\end{abstract}

Keywords: Cadmium, hemoglobin, toxic stress, vitamin E.

\section{Introduction}

Cadmium can be found encountered in the environment as a result of human activity activities such as the use of fossil fuels, burning and destroying metallic wastes, or using of $\mathrm{Cd}$ as a pigment in the dye industry, etc. (Goran, 2018; Goran et al., 2019; Dobre, 2019). In the case of humans the most important source of cadmium in daily life is cigarette smoke.

In the body, cadmium is transported through the blood to the liver. Here, it is attached to specific proteins that transport these toxic elements to the kidneys. This is where the accumulation of cadmium occurs, accompanied by the alteration of glomerular ultrafiltration, followed by the loss of plasmaproteins andbloodglucose. In the conditions of an affected excretory function, elimination of metabolites by the digestive tract induces diarrhea and vomiting, and their accumulation in the body leads to nervous injury and nervous disorders. The mechanism of cadmium toxicity is manifested by binding to mitochondria, where it induces the inhibition of cellular respiration and oxidative phosphorylation (Crivineanu et al., 2000). It also induces the formation of lipid peroxides and other reactive oxygen species, molecules that induce 
damage to the integrity of cell membranes, in all tissues, but in the liver in particular (Gajaila, 2002). Other date also suggests that vitamin E (Vit E), through its antioxidant capabilities, may act as a protective factor against the specific pathogenic effect of cadmium.

Considering the aspects mentioned above, our research focused on highlighting the hematological effects induced by cadmium toxicity. Based on the quantification of these effects we tried to underline a possible protective effect of vitamin E, against the intoxication with this chemical element.

\section{Materials and Methods}

In our experiment we used 18 Wistar female rats, with body weights of 120-170 g. These animals originated from the authorized establishment for laboratory animals of our institution. Our experiment was conducted within the authorized establishment for laboratory animals of our institution. Here all the legal conditions regarding the accommodation and handling of the experimental animals were fulfilled. Our experiment was authorized by the ethics committee of our institution, satisfying the conditions imposed by the EU Directive 63/2010. The animals were housed in special cages, being provided with a feed ratio of 35-60 grams of specific compound feed, per head of animal / day. Furthermore, a volume of water of $25-40 \mathrm{ml}$ / animal / day was assured. The experimental animals were divided into 3 experimental groups $(n=6)$. The experiment lasted 9 days. On day 7 of the experiment, the rats from groups 2 and 3 received cadmium chloride in a dose of $3 \mathrm{mg} / \mathrm{kg}$ orally (by gavage). On days 5-7 of the experiment, the rats in group 3 received Vitamin $\mathrm{E}$ in the dietary ration. It was mixed, under the conditions of our laboratory with prefabricated food, in the proportion of 500 mg Vitamin E / $1000 \mathrm{~g}$ of feed. On day 9 of the experiment, rats from all 3 experimental groups were subjected to the blood sampling operation. Thus, blood samples were collected through the puncture of the coccygeal vein, which did not require anesthesia of the animals. The animals were not euthanized at the end of the experiment, because the induced intoxication was low in intensity, which led to their recovery within about 2 weeks after the experiment. The blood samples collected were used to determine the hematocrit, hemoglobin concentration, as well as the value of erythrocytes and leukocytes in the blood fluid (Paulev, 1999; Codreanu, 2018). The results were statistically processed, calculating the mean and standard deviation. The statistical significance of the differences between groups was evaluated using the $\mathrm{T}$ test (Student).

\section{Results and discussions}

Our results indicate a low level of erythrocytes per volume unit of blood, in the case of group 3 (Cd treated rats) compared to group 1 (control) and lot 2 (Cd + VitE). This difference, statistically significant is $7.40 \%$ in the first case and $8.44 \%$ in the second. This shows the anemia inducing effect of cadmium intoxication. These results coincide with those published by Hounkpatin et al. (2012), which indicate a similar effect in cadmium and mercury intoxicated rats. The anemia inducing effect of Cadmium intoxication could be explained by the functional impairment of the kidney and liver of the intoxicated animals. Probably the levels of erythropoietin are affected, but also other essential components of erythropoiesis, which are released under normal conditions by the liver. This fact could be investigated during further research. There are no significant differences between groups 1 (Control) and 2 $(\mathrm{Cd}+\mathrm{VitE})$, a sign that vitamin E could play an effective protective role. Vitamin E, through its specific and proven antioxidant capabilities, could protect cell membranes as a generality but also at the particular level of organs affected by the toxic aggression of cadmium (Tab. 1).

Regarding the hematocrit, our results indicated a low level in group $3(\mathrm{Cd})$, compared to groups 1 (Control) and $2(\mathrm{Cd}+$ Vit E). This difference, statistically significant, is $9.90 \%$ in the first case and $8.3 \%$ in the second. These results are in accordance with those obtained by us in the evaluation of the number of red blood cells. This confirms the anemia inducing effect of cadmium intoxication, cited by other authors such as Hounkpatin et al. (2012). Also, between group 1 (Control) and $2(\mathrm{Cd}+\mathrm{VitE})$ there are no significant differences, suggesting a possible protective effect of vitamin $E$ in case of this intoxication (Tab. 1). 
Table 1. Number of red blood cells, hematocrit, hemoglobin and leukocytes in the three experimental groups of animals (Mean \pm SD)

\begin{tabular}{|c|c|c|c|c|}
\hline $\begin{array}{l}\text { Group } \\
\text { no }\end{array}$ & $\begin{array}{l}\text { Number of erytrocites } \\
\text { (millions } / \mathrm{mm}^{3} \text { blood) }\end{array}$ & $\begin{array}{l}\text { Hematocrit } \\
(\%)\end{array}$ & $\begin{array}{l}\text { Hemoglobin } \\
\text { (g/dl) }\end{array}$ & $\begin{array}{l}\text { Number of leukocytes } \\
\text { (thousands } / \mathrm{mm}^{3} \text { blood) }\end{array}$ \\
\hline 1 & $8.375 \pm 0.13$ & $42 \pm 2.44$ & $13.73 \pm 0.52$ & $5.74 \pm 0.12$ \\
\hline 2 & $8.38 \pm 0.41$ & $42.5 \pm 1.04$ & $13.86 \pm 0.61$ & $5.83 \pm 0.47$ \\
\hline 3 & $8.16 \pm 0.10^{*}$ & $36.3 \pm 5.20^{*}$ & $12.6 \pm 0.65^{*}$ & $7.02 \pm 0.74^{*}$ \\
\hline
\end{tabular}

Note: ${ }^{*} \mathrm{P}<0.05$

A low hemoglobin level was obtained in the case of group $3(\mathrm{Cd})$, compared with groups 1 (Control) and 2 (Cd + VitE). This difference, statistically significant, is $7.20 \%$ in the first case and $5.7 \%$ in the second. These results are consistent with those referring to erythrocyte level and hematocrit, underlining the anemic effect of cadmium intoxication. These results are concordant with the data reported by Kostich et al. (1993). There are no significant differences between group 1 (Control) and 2 (Cd + VitE), suggesting, again, a possible protective effect of vitamin $\mathrm{E}$ in this intoxication (Tab. 1).

A significant increase in the number of leukocytes per volume unit of blood was observed in the case of group $3(\mathrm{Cd})$, compared with groups 1 (Control) and 2 (Cd + VitE). This increase is $6.77 \%$ in the first case and $7.71 \%$ in the second. These results indicate obvious toxic stress induced by the conditions of the experiment imagined by us. These results are in full accordance with the data reported by Lee et al. (1990) and Davis et al. (2008), which indicates an amplification effect of leukocyte levels in the blood, an effect the author could explain as an inflammatory state induced by this intoxication. There are no significant differences between group 1 (Control) and group $2(\mathrm{Cd}+\mathrm{VitE})$, suggesting, this time, also, a possible protective effect of Vitamin $\mathrm{E}$ in case of this intoxication (Tab. 1).

\section{Conclusions}

In the case of rats intoxicated with cadmium, we found a significant decrease in the number of red blood cells, hematocrit but also of the hemo- globin. We succeeded in highlighting a significant increase in the level of leukocytes in the blood, in the case of cadmium intoxicated rats, compared to those in the control group. In the case of rats treated with cadmium and vitamin E, no significant differences were found compared to the control group.

Acknowledgments. This research did not receive any specific grant from funding agencies in the public, commercial, or not-for-profit sectors.

\section{References}

1. Codreanu I (2018). Animal physiology, Ed. Printech, București.

2. Crivineanu V, Crivineanu M, Dobre IR, Goran GV (2000). Cadmiul - factor cancerigen la animale şi om, Conferinţa Naţională de Oncologie Comparată, Sibiu, Romania.

3. Davis AK, Maney DL, Maerz JC (2008). The use of leukocyte profiles to measure stress in vertebrates; a review for ecologists. Funct Ecol. 22:760-772.

4. Dobre IR (2019). Toxicologie veterinara, Ed. Printech.

5. Gajaila G (2002). Imunologie analitică. Aspecte fundamentale și metodologice, Ed. Printech, București

6. Goran GV (2018). Veterinary Toxicology - volume 1, Ed. Ex Terra Aurum.

7. Goran GV, Badea E, Buga M L, Crivineanu V (2019). Cadmium, lead and Zinc levels in organic and conventional eggs, Agrolife Scientific Journal, 8(1):107-112.

8. Hounkpatin ASY, Johnson RC, Guedenon P, Domingo E, Alimba CG, Boko M, Eborh PA (2012). Prottective effect of vitamin $\mathrm{C}$ on haematological parameters in intoxicated Wistar rat with cadmium and mercury. International Research Journal of Biological Sciences, 1(8):76-81.

9. Kostich MM, Ognanovich B, Dmitrijevich S, Zikici RV, Rozich GL, Zivkovich RV (1993). Cadmium induced 
changes of antioxidant and metabolic status in RBC of rats. European J. Haematol, 51(2):86-92.

10. Lee JS, Keneth L, White MS (1990). A review a health effect of cadmium. American Journal of Industrial Medicine, 1(3-4):307-317.
11. Paulev PE (1999). Textbook in Medical Physiology and Pathophysiology, Essentials and clinical problems, Copenhagen Medical Publishers. 